\title{
FH Gene Mutation
}

National Cancer Institute

\section{Source}

National Cancer Institute. FH Gene Mutation. NCI Thesaurus. Code C51305.

A change in the nucleotide sequence of the $\mathrm{FH}$ gene. 